\title{
Delayed Diagnosis Due to Septal Perforation in Patient with Extranodal Natural Killer/T-Cell Lymphoma, Nasal Type
}

\author{
Eun Soo Lee ${ }^{1}$, Woo Yong Bae ${ }^{1} \mathbb{D}$, Changbae Lee ${ }^{1}$, and Min Gyoung Park ${ }^{2}$ \\ ${ }^{1}$ Departments of Otorhinolaryngology-Head and Neck Surgery, ${ }^{2}$ Pathology, College of Medicine, Dong-A University, Busan, Korea
}

\author{
비중격 천공에 의해 늦게 진단된 결절외 비성 Natural Killer/T 세포 림프종 1예 \\ 이은수 ${ }^{1} \cdot$ 배우용 $^{1} \cdot$ 이창배 ${ }^{1} \cdot$ 박민경 $^{2}$ \\ 동아대학교 의과대학 이비인후과학교실, ${ }^{1}$ 병리학교실 $^{2}$
}

\author{
Received April 8, 2019 \\ Revised May 19, 2019 \\ Accepted June 19, 2019 \\ Address for correspondence \\ Woo Yong Bae, MD, PhD \\ Department of Otorhinolaryngology- \\ Head and Neck Surgery, \\ College of Medicine, \\ Dong-A University, \\ 26 Daeshingongwon-ro, Seo-gu, \\ Busan 49201, Korea \\ Tel +82-51-240-5428 \\ Fax +82-51-253-0712 \\ E-mail doncamel@dau.ac.kr
}

\begin{abstract}
Extranodal natural killer (NK)/T-cell lymphoma, nasal type is a rare non-Hodgkin lymphoma originating in the nasal cavity or in the paranasal sinuses, and is etiologically closely related with the Epstein Barr Virus infection. It is more commonly found in East Asia, South America, and Mexico than in Europe or North America. Extranodal NK/T-cell lymphoma, nasal type typically shows a crust on the nasal mucosal surface, necrosis, and inflammation. Pathologically, it presents as significant vascular damage and destruction, with apparent tissue necrosis and cytotoxicity. These neoplasms are very aggressive and can show septal perforation, diffuse ulcer lesion on the nasal mucosa, fistula or epistaxis. We experienced a case of the extranodal NK/Tcell lymphoma, nasal type at the nasal septum, which was delayed in diagnosis due to septal perforation, which occurred after septoplasty in a 47-year-old female. Thus, we report this case with a review of literatures.

Korean J Otorhinolaryngol-Head Neck Surg 2020;63(5):223-7
\end{abstract}

Key Words Nasal septal perforation · Lymphoma, extranodal NK-T-Cell · Surgery.

\section{서 론}

Extranodal natural killer(NK)/T-cell lymphoma, nasal type은 비호지킨 림프종의 아형 중 하나로 비교적 그 빈도가 드물다. 이 질환은 지역에 따라 발생 빈도에 차이가 있는 것 으로 알려져 있는데, 유럽과 북미지역에서 발생하는 비호지 킨 림프종의 $0.3 \%$ 를 차지하며, 중남미지역의 비호지킨 림프 종의 $1.2 \%$, 아시아 지역의 비호지킨 림프종의 $1.5 \%$ 를 차지하 고 있다. ${ }^{1)}$ 대부분 중년 연령층에서 발생하는데 여성에 비해 남성에서 높은 발생빈도를 보인다. ${ }^{2}$ 이 질환은 Ebstein Barr Virus(EBV)의 잠복감염과 관련되어 있으며 주로 비강 및 부 비동, 안면 중앙을 침범하지만, 드물게 피부, 위장관계, 고환,

This is an Open Access article distributed under the terms of the Creative Commons Attribution Non-Commercial License (https://creativecommons.org/licenses/by-nc/4.0) which permits unrestricted non-commercial use, distribution, and reproduction in any medium, provided the original work is properly cited.
중추신경계, 폐 침샘, 골수, 후두에도 생길 수 있다.,4)

비강 내에 원발하는 경우 비점막에 광범위한 궤양이 형성 되며 비중격 천공, 비출혈 등을 동반하기도 한다. 일반적으로 초기에는 비폐색이나 비출혈, 농성 비루 등 비특이적 증상이 나타나며 명확한 종괴 소견이 보이기 전에는 염증성 질환으 로 오인되기 쉽다.

진단은 병리조직학적 검사로서, 임상증상 및 국소 소견이 의심될 때 조직 생검을 한다. 비정형 세포들이 괴사 부위에 흩어져 있어 만성 염증 소견만을 보이는 경우가 많으므로 가 피 아래에 있는 조직을 채취해야 한다. 조직 검사가 제대로 되지 않은 경우 진단이 늦어질 수 있다.

저자들은 이전에 타 병원에서 비중격 교정술 후 발생한 비 중격 천공으로 인해 늦게 진단된 extranodal NK/T-cell lymphoma, nasal type 증례를 경험하였기에 문헌고찰과 함 께 보고하는 바이다. 


\section{증 례}

47세 여자 환자가 수년 전부터 지속된 비강 폐색을 주소로 타 병원에서 2년 전 양측 하비갑개 성형술을 시행하였고 술 후에도 증상이 지속되어 1 년 후 같은 병원에서 비중격 교정 술을 시행하였다. 이후 비폐색 증상은 호전되었으나 가피 형 성 및 비루 증상이 지속되어 본원 외래로 내원하였다. 환자 는 과거력상 특이 병력은 없었다.

비강 내시경 검사상 약 $6 \sim 7 \mathrm{~mm}$ 정도 크기의 비중격 천공 소견을 보였으며 비중격 천공 주변에 가피, 염증 소견이 관찰 되었다(Fig. 1A). 외래 첫 내원 2주 후 촬영한 전산화단층촬 영(CT)에서 비중격 천공 주변 미세한 점막 비대 소견 외 다른 비강이나 부비동에서 특이사항은 관찰되지 않았다(Fig. 2).

비중격 연골염 진단하 외래에서 약 1 개월간의 2 세대 세팔 로스포린, 마크로라이드 계열 항생제 및 연고치료 후 증상
다소 호전되어 주기적인 경과 관찰을 시행하였다(Fig. 1B). 외래 방문 3개월 후 다시 비폐색 증상 발생하여 시행한 비강 내시경 검사상 비중격 천공 부위 주변 점막이 두꺼워지고 딱 지가 많이 증가된 소견이 관찰되었다(Fig. 1C). 이에 약물치 료를 다시 시행하였지만 이전과 달리 약물치료 1 개월 후에도 두꺼워진 점막 소견의 호전은 보이지 않고 가피 형성이 악화 되어 심한 비강 폐색 증상을 호소하였다. 이에 비중격 연골 염 혹은 육아종성 질환으로 진단하고 점막 절제 및 생검을 시행하기로 하였다(Fig. 1D).

수술은 병변의 범위가 커 전체 절제와 더불어 조직 검사를 목적으로 전신마취하에서 시행하였으며 내시경을 이용하여 진행되었다. 수술 시 육안적 소견상 비중격 천공 부위 염증 소 견을 동반한 비특이적 점막 비대 소견과 연골의 비대 소견이 관찰되었다. 육아종성 조직으로 의심하였던 점막 비대 부위 전연을 연골 부위와 함께 절제한 후 비강패킹을 시행하였다.
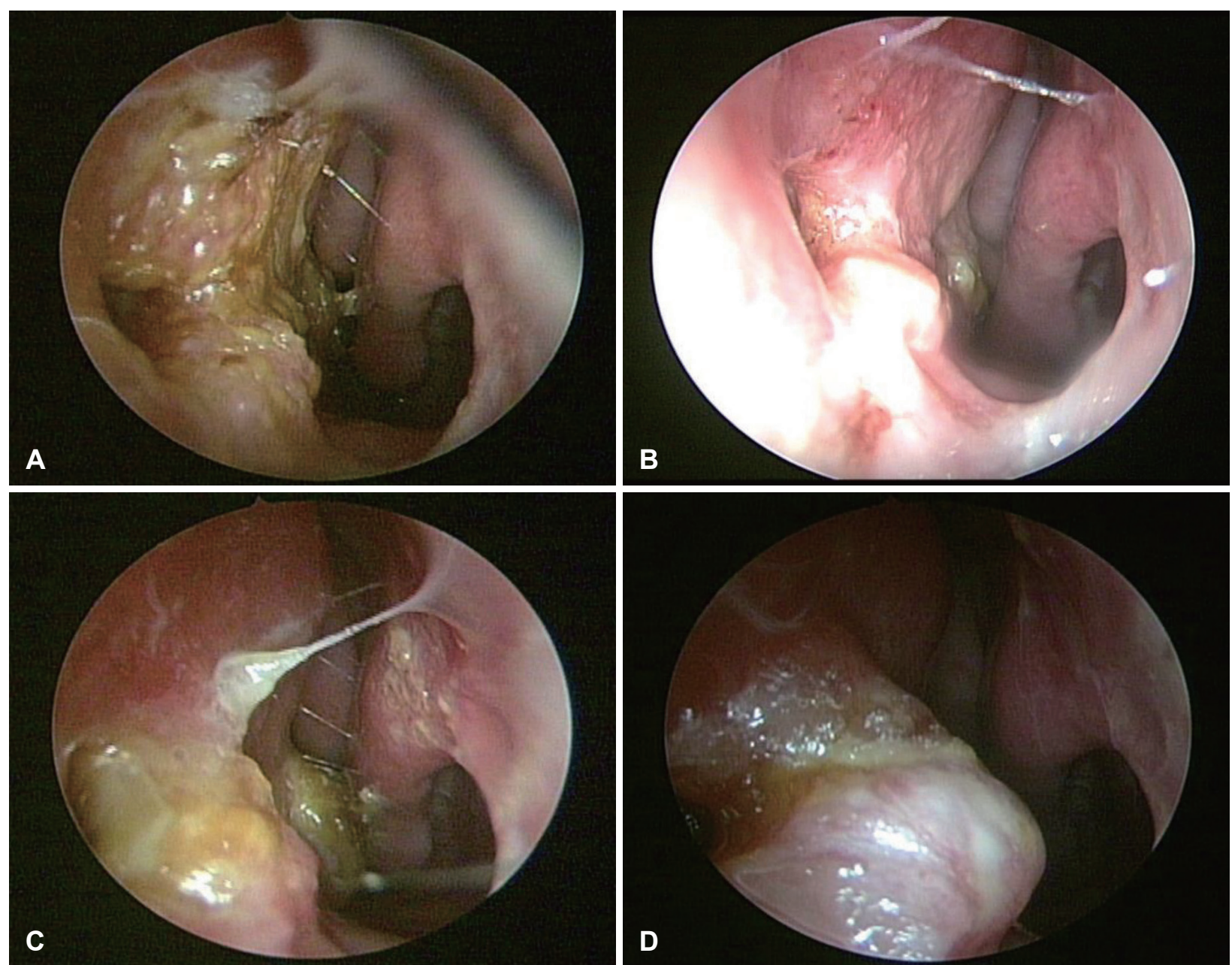

Fig. 1. Endoscopic examination of case. At first visit, Endoscopy shows nasal crusts with inflammation around septal perforation (A). After medication therapy about 1 month, endoscopy shows relief of inflammation around septal perforation (B). 3 months after first visit, endoscopy shows mucosal thickening and nasal crusts around septal perforation (C). 4 months after first visit, endoscopy shows aggravation of mucosal thickening and nasal crusts around septal perforation despite of medication therapy about 1 month (D). 


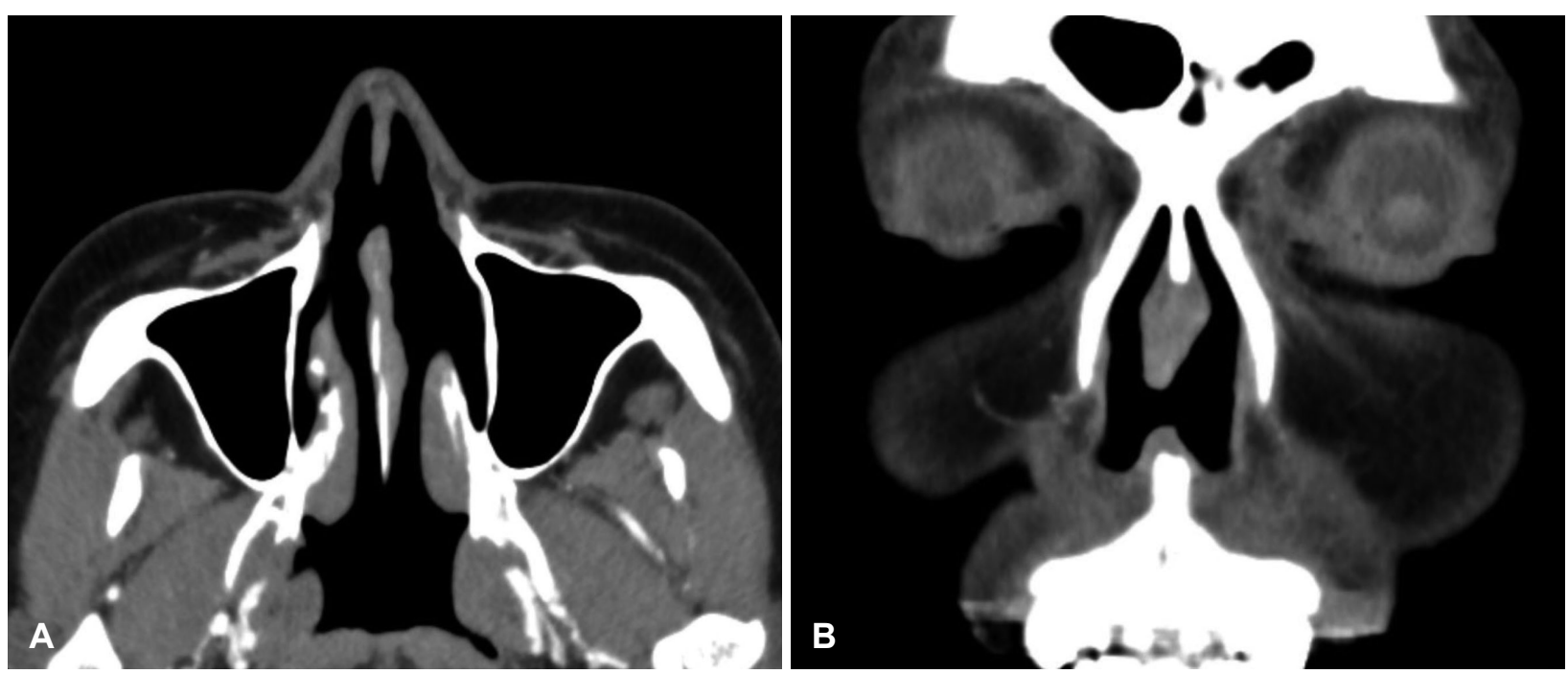

Fig. 2. Preoperative CT scan. Axial CT scan shows about 6-7 mm sized septal perforation and mild mucosal thickening at posterior portion of septal perforation (A). Coronal CT scan shows septal perforation and no abnormal enhancement (B).
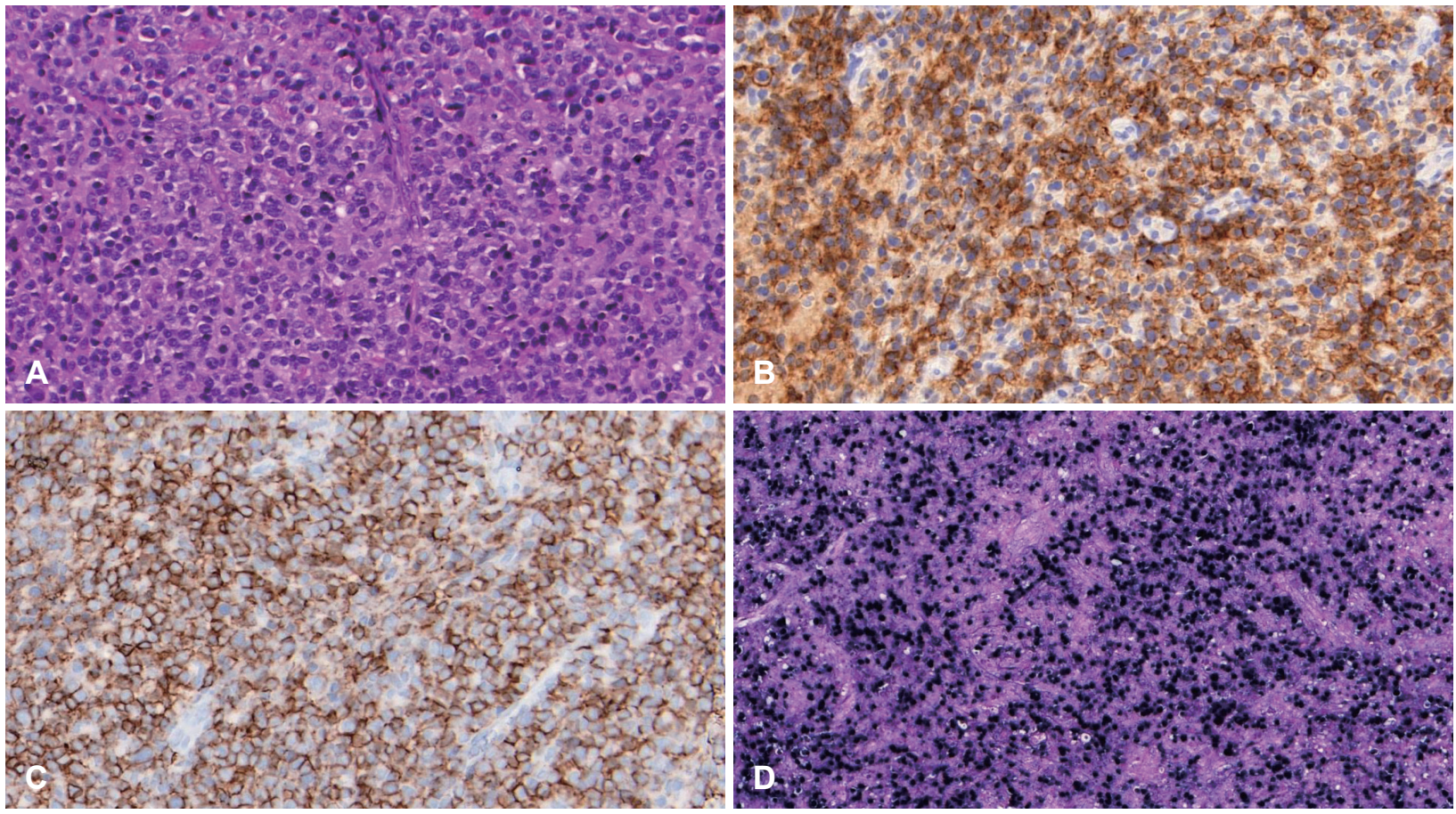

Fig. 3. Histologic and Immunohistochemical findings. Medium-sized atypical lymphoid cells that destroyed normal nasal mucosal structure (hematoxylin and eosin staining, $\times 200)(A)$. Tumor cells positive for anti-CD30 antibody $(\times 200)(B)$. Tumor cells positive for anti CD56 antibody $(\times 200)(C)$. Tumor cells positive for Ebstein Barr Virus in situ hybridization ( $\times 100)(D)$.

점막 비대 부위 조직 검사 결과, 정상 비점막 구조를 모두 파괴하고 광범위하게 자라는 종양이 관찰되었다. 종양은 대개 중간 크기의 세포로 구성되어 있었고, 주로 혈관 주변으로 증 식하는 양상을 보였다(Fig. 3A). 종양 세포들은 CD30, CD56 면역조직화학 검사와 EBV 제자리 부합법 반응(in situ hybridization) 검사에서 강한 양성을 보이고(Fig. $3 \mathrm{~B}, \mathrm{C}$, and D)
다른 상피성 암종이나 PD-1, ALK 등 다른 종류의 림프종에 특이적인 면역화학조직 염색에 음성을 보여 extranodal NK/ $\mathrm{T}$-cell lymphoma, nasal type으로 최종 진단되었다.

원격전이 여부를 확인하기 위해 시행한 양전자방출 단층 촬영술 $(\mathrm{PET}-\mathrm{CT})$ 에서 비중격에 비정상적 섭취 증가 신호는 보이지 않았고, 원격전이도 관찰되지 않았다. 진단 후 종양 
내과, 방사선종양학과와 협진 진료를 시행하였고, 현재 cisplatin 항암화학요법 및 국소 방사선치료와 이비인후과적 술 후 치료 병행 중에 있다.

\section{고 찰}

Extranodal NK/T-cell lymphoma, nasal type의 증상은 비강 폐색, 악취성, 농성 비루, 비출혈 등 비교적 비특이적이 며 비강내시경 검사에서 광범위한 점막 궤양 소견, 염증, 가 피 형성, 종괴 소견 등이 관찰될 수 있다. 이 질환만의 특이적 인 임상적 또는 조직학적 특성들이 없기 때문에 타 질환과의 감별진단이 필요하다. 비중격 천공의 주 증상은 가피 형성, 비폐색, 콧물, 비출혈, 적성음 등이 있고 때로는 통증, 건조감, 악취 등을 호소하기도 한다. 가피 형성과 비출혈은 천공의 변 연부에서 주로 발생한다. 이는 천공 부위의 노출된 연골 부 위를 비중격 점막이 덮어주지 못하여 연골 부위 염증이 발생 하기 때문이다. ${ }^{6)}$

본 증례의 경우 본원에 내원 시 비강 폐색, 비루, 비강 가피 를 호소하였으나, 술 후 비중격 천공 부위 연골염에 의한 증 상과 유사하여 종양에 의한 증상으로 보기가 어려웠다. 또한 이미 수술 후 발생한 비중격 천공 때문에 종양에 의한 병변 을 확인할 수 없었으며 수술 전의 이상 소견에 대해 확인할 수가 없었다. 이처럼 명확한 종괴 소견 혹은 괴사 소견을 보 이기 전에는 염증성 질환으로 오인하여 쉽게 악성 종양의 가 능성을 염두에 두기 힘들다.

확진을 위해서는 조직 검사와 추가적인 면역조직화학 염색 이 필요하다. 전형적인 현미경 소견은 괴사가 자주 동반되고 혈관 증식과 더불어 혈관을 중심으로 증식하는 종양세포가 관찰되는 것이다. 추가 면역조직화학 염색에서는 CD3 등의 $\mathrm{T}$-세포 계열 항원보다는 CD16, CD56, CD57 등의 NK-세포 계열 항원을 발현하는 것이 특징적이다. ${ }^{7)}$

$\mathrm{NK} / \mathrm{T}-$ cell lymphoma는 $\mathrm{EBV}$ 의 잠복감염과 강한 연관 이 있어 종양 조직에서 제자리 부합법 반응 검사 시 종양세 포에서 $\mathrm{RNA}$ 를 인코딩하는 $\mathrm{EBV}$ 검출이 가능하다. ${ }^{8)}$ 본 증례 에서도 비대 점막 조직에서 $\mathrm{EBV}$ 에 대한 제자리 부합법 반응 검사 시행 결과 전반적 양성반응을 보였다.

병소가 상기도에 국한되어 있고 전이가 없는 초기라면 해 당 부위의 방사선요법이 일반적인 치료 방법이다. 진단 당시 경부림프절 전이가 있는 경우에만 조사 부위에 경부림프절 을 포함한다. 최근에는 국소 제어 실패와 원격전이를 막기 위 해 치료 초기부터 방사선치료와 항암화학요법을 병행하는 경향이 있다. ${ }^{9)}$ 위 환자도 종양내과 및 방사선 종양학과 협진 하에 현재 cisplatin 항암화학요법 및 국소 방사선치료와 이
비인후과적 술 후 치료 병행 중에 있다.

Extranodal NK/T-cell lymphoma, nasal type의 전산화 단층촬영(CT) 소견으로는 침윤(infiltration) 양상이 $69 \%$, 고형 종양(polypoid) 양상이 $27 \%$, 혼합 양상이 $4 \%$ 를 차지하 였다. 대부분의 경우 정상 근육과 비슷한 밀도를 보이며 균 질한 양상이었다. 괴사 혹은 궤양 소견을 동반한 경우는 $21 \%$ 였고, 골파괴 소견을 동반한 경우는 $17 \%$ 였다. ${ }^{10)}$ 전산화단층 촬영(CT) 소견이 전반적으로 비특이적이며 비강 점막 괴사, 골파괴 소견이 동반되지 않을 수 있기 때문에 임상 양상과 비특이적 점막 소견만으로도 악성 종양을 염두에 두고 빠르 게 생검을 시행하는 것이 진단이 지연되는 것을 막을 수 있 다. ${ }^{11)}$ 본 증례에서는 전산화단층촬영(CT)에서 비중격 천공 소견 이외에 다른 비강이나 부비동에서 특이사항은 관찰되 지 않았다.

환자가 비특이적 증상을 호소하며, 비강내시경 검사상 악 성 종양을 시사할 만한 점막 소견이 관찰되지 않을 시 병변 이 진행될 때까지 진단을 놓칠 수가 있다. 본 증례에서는 악 성 종양의 발생이 비중격 교정술 전이었는지, 혹은 술 후 발 생한 비중격 천공의 연골염에 이차적으로 병발한 것인지 쉽 게 추정할 수 없다. 하지만 발생 시기에 관계없이 증상 및 비 강 내 점막 소견으로는 단순 염증인지 악성 종양인지 감별하 기 어려웠다. 또한, 술 후 발생한 비중격 천공으로 인해 증상 발생 시의 병변을 확인할 수 없었던 점과 천공 부위 연골염 소견을 보였던 점도 진단을 어렵게 했다.

위 증례를 통해 명확한 종괴 소견이 보이지 않더라도 약물 치료에도 지속되는 염증 소견 혹은 장기간 비특이적 증상을 호소하는 경우에 악성 종양을 염두에 두고 정확하고 빠른 절 제 생검이 필요하다는 것을 시사하는 바이다. 적절한 보존적 치료에도 불구하고 증상이 지속될 경우에는 악성 종양을 의 심해야 하며 악성 종양을 감별하기 위한 조직 생검을 시행해 야 한다. ${ }^{5)}$ 조직 검사는 충분한 양을 얻지 못하거나 가피 부분 에서 떼어낸 경우 단순히 만성 염증으로 판명되어 재생검해 야 하는 경우가 많으므로 충분한 양의 조직을 떼어내야 한다.

저자들은 이전에 타 병원에서 비중격 교정술 후 발생한 천 공 부위의 염증소견으로 인해 늦게 진단된 extranodal NK/ $\mathrm{T}$-cell lymphoma, nasal type을 경험하였기에 문헌고찰과 함께 보고하는 바이다.

\section{Author Contribution}

Conceptualization: Woo Yong Bae. Formal analysis: Changbae Lee. Investigation: Eun Soo Lee. Methodology: Woo Yong Bae. Supervision: Woo Yong Bae. Validation: Min Gyoung Park. Visualization: Min Gyoung Park. Writing_original draft: Eun Soo Lee. Writing — review \& editing: Woo Yong Bae. 


\section{ORCID}

Woo Yong Bae

\section{REFERENCES}

1) Haverkos BM, Pan Z, Gru AA, Freud AG, Rabinovitch R, XuWelliver M, et al. Extranodal NK/T cell lymphoma, nasal type (ENKTL-NT): An update on epidemiology, clinical presentation, and natural history in North American and European cases. Curr Hematol Malig Rep 2016;11(6):514-27.

2) Tlholoe MM, Kotu M, Khammissa RA, Bida M, Lemmer J, Feller L. Extranodal natural killer/T-cell lymphoma, nasal type: 'Midline lethal granuloma.' A case report. Head Face Med 2013;9:4.

3) Al-Hakeem DA, Fedele S, Carlos R, Porter S. Extranodal NK/ T-cell lymphoma, nasal type. Oral Oncol 2007;43(1):4-14.

4) Slater DN. The new World Health Organization-European Organization for Research and Treatment of Cancer classification for cutaneous lymphomas: A practical marriage of two giants. $\mathrm{Br} \mathrm{J}$ Dermatol 2005;153(5):874-80.

5) Mahir K, Riad K, Noam Y, Rabia S. NK/T-cell lymphoma presenting as a post-operative nasal septal perforation: A diagnostic challenge. J Otolaryngol Rhinol 2018;4(1):037.

6) Fairbanks DN. Closure of nasal septal perforations. Arch Otolaryngol 1980;106(8):509-13.

7) Kwong YL. Natural killer-cell malignancies: Diagnosis and treatment. Leukemia 2005;19(12):2186-94.

8) Weiss LM, Chen YY. EBER in situ hybridization for Epstein-Barr virus. Methods Mol Biol 2013;999:223-30.

9) Kim SJ, Yoon SE, Kim WS. Treatment of localized extranodal NK/T cell lymphoma, nasal type: A systematic review. J Hematol Oncol 2018;11(1):140.

10) Kim J, Kim EY, Lee SK, Kim DI, Kim CH, Kim SH, et al. Extranodal nasal-type NK/T-cell lymphoma: Computed tomography findings of head and neck involvement. Acta Radiol 2010;51(2):164-9.

11) Guan P, Chen Z, Chu L, Zhen L, Zhang L, Pan L, et al. Extranodal NK/T-cell lymphoma in adolescents: Imaging findings of a consecutive 7-year case series. J Int Med Res 2019;47(3):1210-20. 